\title{
Multimedia for Teaching and Learning Among Trainers in TVET Institution
}

\author{
Fairul Nizar Rahmat ${ }^{1}$, Fakhrurrazy Abu Yazid ${ }^{2}$, Raja Noredawati Raja Daud ${ }^{3}$, \\ Kamazrul Zefrin Kaulan ${ }^{4}$, Mohamad Hisyam Mohd. Hashim ${ }^{5}$ \\ ${ }^{1}$ Kolej Komuniti Bandar Penawar, Johor, Malaysia \\ ${ }^{2}$ Sekolah Kebangsaan Tan Sri Ghazali Jawi, Johor, Malaysia \\ ${ }^{3}$ Sekolah Kebangsaan Canossian Convent, Johor, Malaysia \\ ${ }^{4}$ Sekolah Kebangsaan Setia Jaya, Johor, Malaysia \\ ${ }^{5}$ Faculty of Technical and Vocational Education, Universiti Tun Hussein Onn Malaysia, Malaysia
}

\section{Email address:}

nizarmediator@gmail.com (F. Z. Rahmat), fakhrurrazy_abuyazid@yahoo.com (F. A. Yazid), 7269hryaty@gmail.com (R. N. R. Daud), alfatih2319@gmail.com (K. Z. Kaulan), mhisyam@uthm.edu.my (M. H. Mohd. Hashim)

\section{To cite this article:}

Fairul Nizar Rahmat, Fakhrurrazy Abu Yazid, Raja Noredawati Raja Daud, Kamazrul Zefrin Kaulan, Mohamad Hisyam Mohd. Hashim. Multimedia for Teaching and Learning Among Trainers in TVET Institution. International Journal of Vocational Education and Training Research. Vol. 2, No. 3, 2016, pp. 18-23. doi: 10.11648/j.ijvetr.20160203.11

Received: December 22, 2015; Accepted: February 25, 2016; Published: May 17, 2016

\begin{abstract}
In this era of technological progress of ICT, multimedia technology is an important medium in disseminating information in teaching and learning while trainers play a vital role for the success of the application of multimedia technology. Therefore, this study aimed to review the use of multimedia among trainers of technical teaching and learning skills in three institutions, namely Pusat Giat MARA Pengerang, Bandar Penawar Community College, and the Bandar Penawar National Youth Skills Institute, The study involves technical trainers in Pengerang, Johor. The instrument that was used is a set of questionnaire which is divided into three parts. Data were analyzed using the Statistical Package for Social Science, Version 12.0 (SPSS). The data presented in the form of the percentage, mean, standard deviation and frequency. The results showed that the method used is software that is like 'Guide', 'Simulation' 'Drills' and' Demonstration'. While aspects of the operation of computer skills among technical trainers is very high aspect mastery. Results may also indicate no trainers who never use multimedia software for teaching. Through this study, a number of actions can be taken to improve the multimedia and ICT skills to trainers, such as by increasing technical courses and computer skills multimedia such as intensive courses, workshops and the like to produce their own multimedia software related to the subjects being taught.
\end{abstract}

Keywords: Multimedia, Software, Technical Trainers

\section{Introduction}

The Malaysian education system has undergone rapid changes due to technological progress and present sciences. To improve the quality of education, national education policies and curricula are constantly being constantly modified according to changing times to ensure the effective implementation in the face of the new millennium. In line with the desire of countries to achieve the country's vision, which requires productive growth that can be achieved through technological expertise, manpower capable of critical thinking, creative and innovative and be ready to compete in the global economy. Advances in multimedia technology also promise great potential in changing the way people learn, how to get information, how to adjust any information and so on. Multimedia also provides opportunities for educators to apply various teaching techniques and students were given the opportunity to learn techniques that are appropriate to them, form a knowledge base on their needs and experience of the learning process more interesting and efficient. Resource and referral information also is no longer bound by the text of the book alone, but more broadly than that. Multimedia technology via the Internet can enhance information access process where each information in a variety of forms and approaches can be accessed easily and quickly. 
The application of computer technology is the latest method to increase the effectiveness of communication in teaching. However, the extent to which trainers in technical skills institute take advantage of existing computer technology is not known. A study conducted [7] which studied the use of teaching aids among trainers in secondary vocational schools craftsmanship that is now known by the name of vocational colleges in Malaysia found the use of non-electronic teaching aids are preferred such as the use of a chalkboard, and electronic fuel highly rarely used. The use of multimedia as teaching aids supplied by the Ministry of Education for his ideas is to facilitate the teaching and learning ( $\mathrm{T} \& \mathrm{~L}$ ) in school. In addition to disclosing to a form of teaching and learning up to date, it is considered to be an attraction for students and also facilitate everyone, trainers, students, department heads, administrators, departments and ministries. What about the supply of trainers in Institutional skills with orientation between computer and T \& L material? Students will be more interested in using technology in their learning process. This statement supported [9] states expect students learning interesting and challenging, and very interested in the use of technology.

The use of multimedia among teachers at the institute skill is very important. There are some obstacles for teachers to use multimedia in teaching and learning as knowledge and skills they apply multimedia. Which states that teachers are using technology is caused by a lack of knowledge and lack of skills in using ICT in the classroom [1]. Are they willing to use materials such as orientation between $\mathrm{T} \& \mathrm{~L}$ and computer multimedia software? Therefore, the main concentration of researchers in this study was to determine whether trainers use teaching methods aided teaching aids or media teaching software-based multimedia optimally can make teaching and learn more effective and interesting.

\subsection{The Objective of the Study}

The study aims to determine the level of multimedia skills and the use of multimedia software expertise in the area of TVET in Pengerang. Among the objectives of the study are: -

i. Identify the skill level multimedia among instructors at the institute skill.

ii. Identify the level of use of multimedia by trainers at the institute skill.

\subsection{Research Interest}

Development of science and technology now demands that humans master ICT skills are increasingly important to people now. Someone would say outdated it is not aware of or do not know to apply it, therefore, basic knowledge about it is deemed necessary to meet the challenges of an increasingly challenging world globalization this. The results of this study are important as a reference to provide the information related to the institutional skills to make revisions to the training of trainers program conducted. In addition, it can evaluate the level of multimedia skills and the use of multimedia among trainers at the institute of skills that are in line with technological developments and the objective now. It also facilitates the planning of institutional skills, training or internal courses for revealing the current development of teaching and learning based on multimedia software so that trainers can correct the information and follow the changes in the TVET system to produce highly skilled students, competent instructors, and institutional development skills.

\section{Literature Review}

What is actually said to be multimedia? Most say that multimedia is the biggest evolution in the field of education and communication after the discovery of the printing machine. Whatever is said or understood about multimedia, all were aware that the computer has changed the way people work and also manage the full information. Computer also plays a key role in bridging the geographical gap in communication and information and human knowledge. Technological developments in the field of multimedia also add more features by enabling computer system not only use the text as a primary source of information distribution but also insert graphic elements, audio, video, animations and interactivity into it. This further improves the ability of a computer usage to the maximum extent.

The use of technology in education is as important as other teaching aid tools in class, in order to facilitate and develop the students understanding pertaining to certain topic which has been taught in class. [12]

\subsection{Definition of Multimedia}

Too many definitions given to multimedia. By [2], multimedia is the integration of sound, music, animation, text, sound, video and graphics generated by computer-based technology. More interesting than the television or VCR. [14] defines it as a combination of sound, static images, hypertext, and video used in accordance with computer technology. He also added that the multimedia as "a group of technology experts to design something to entice and satisfy them among themselves." Opinion [13], multimedia is capable of hyper-media hypertext. Emphasis is given to the ways users combine, edit, adjust the sound, graphics, moving images, text and computer software to use the mouse. From the definitions set out, clearly shows that multimedia is expressed as a computer which is connected with other equipment disc player video, compact disc players, graphic scanners (scanner), synthesizer music, monitor and so on. Generally, it can be said that multimedia as a computer-based interactive communication process which includes the use of text, audio, and graphics and animations.

But in point of education, one of the most common definitions used to define multimedia is; "Video is a set of interactive communication system that is guided by computer for them, storing, transmitting and maintaining the script text, animation, video editing and network information". According [5] "multimedia is a computer-based interactive communication tools which includes the use of audio-visual media such as text, graphics, audio, video, and animation. The 
key element that needs to be discussed when a person needs to build the definition of multimedia:

i. Presentation of information using a combination of text, graphics, sound, animation and video and have interactivity between users and computers.

ii. The system enables access to information for a software application to be made for non-linear (non-linear navigation).

However the simplest definition for multimedia is "computer-based interactive communication process that summarizes using text, graphics, audio, video and animation".

\subsection{Factors in Using Multimedia in Educations}

Here, several factors why the need for the use of multimedia and the Internet in education.

i. Storage space and ease of deployment of multimedia technology enables information to be stored in large quantities more easily than traditional storage methods. Through modern storage technologies such as the use of compact discs, media and information in various formats can be stored more easily without the need for extensive storage space.

ii. Search facilities and access to information. Most of the information and internet applications provide effective information search and allows any of the information required can be achieved in an accelerated pace.

iii. References and strengthening of information through the limitless resources. Through multimedia technology and the Internet, students can obtain a source of information for reference purposes and the consolidation with easier and faster.

iv.Providing power control more flexible learning. Through the use of modern technology, students can master a lesson in learning that they're interested in and enjoy. Multimedia technology and the Internet also provides students with an interactive edge and it can assess and record students' achievement in learning.

v. Effective learning through the use of various media. Scientific research shows that memory process that occurs in the human brain is more easily performed when people receive various consolidation in various forms in a short time. Therefore, the use of images or image is much more than text because it has artistic value and based on the experience of human nature.

vi. The use of multimedia in education: There are various types, form, format, approach and focus of educational multimedia applications which are multimedia education available in the market and rely on the user to make a selection and evaluation before it is first used.

Needless to say, multimedia courseware conveys the lesson massages to student successfully in easier form and more interesting than textbooks or other multimedia, and it is focused on fulfill the various learning strategies.[15]

\subsection{Teaching and Learning in Multimedia}

Curriculum wizard and computer applications in which the curriculum involves interaction with a computer student at the institute for applied skills is important for students so they can learn the teaching materials through instructional methods and computer-aided learning, which is one way of learning the wizard. Teaching materials were used in the form of software that is specially designed to meet the needs of students as appropriate degree of skill, knowledge and a certain time [10]. There are a variety of teaching strategies that can be used in the design of a software update. Including tutorials, exercises and demonstrations. Use of the software is suitable for teaching tutorials, drills, simulations and games [3]. Therefore, teaching and learning methods need to be identified and indirectly to the guide member of the board software, including scriptwriters who are usually composed of Subject Expert Methods, programmers and others to produce the desired software.

\subsection{Multimedia Software in Education}

To ensure a multimedia software built it can be used properly and effectively then it must have consistency with the education system in Malaysia. Trainers are implementing group play an important role in determining success in the use of computer-aided institutions T\&L skills. Multimedia courseware can only act as a resource and a tool in the process of T\&L. The trainer's role is more of a facilitators and driver's knowledge. CLA teaching method seeks to aid the process of teaching and learning something more interesting and effective.

\section{Research Methodology}

The design of this study is a research-based survey with quantitative approach. Survey is a study to examine the phenomenon during an event or happening by taking the data in a certain time as a result of the feedback study involves three lecturers in institutes of skills training. Since the study survey, the questionnaire was used to collect data from respondents. The questionnaire used is as recommended by [8] of the respondents are required to choose based on the Likert response set.

Questionnaires to be the main instrument in this study because these instruments are easily administered and researchers save time during data collection. The questionnaire used was adapted from a survey conducted last year by researchers of [16]. Some modifications have been made to meet the objectives of this study. The questionnaire consists of 40 items and is divided into 3 parts, part A (demographic), part B (knowledge about multimedia) and C (application of multimedia skills in teaching and learning).

\subsection{Population and Sample}

The study population consisted of all trainers in training and skills in the TVET Training Institute in Pengerang, Johor. A total of 40 trainers from three Skills Training Institute has been selected to participate in this study. Through questionnaires that have been built, trainers will be evaluated 
based multimedia skills and the use of multimedia in teaching. Table 1 shows the distribution of the number of samples in accordance with Skills Training Institute.

Table 1. Distribution of sample according to Skills Training Institute.

\begin{tabular}{ll|l}
\hline Num & Institute & $\begin{array}{l}\text { Technical } \\
\text { Trainer }\end{array}$ \\
\hline 1 & Community College Bandar Penawar & 20 \\
2 & National Youth Skill Institute, Bandar Penawar & 10 \\
3 & Pusat Giat Mara Pengerang & 10 \\
& Number of sample & 40 \\
\hline
\end{tabular}

\subsection{Research Instrument}

Instruments questionnaires used in this study was built to answer the research questions. The questionnaire that was developed is divided into three parts, namely Part A, Part B and Part C. In Part A, a questionnaire containing demographic information of the respondents as gender, age, teaching, education level and teaching experience. While section B contains the items related to the skill level of multimedia teaching and Part $\mathrm{C}$ contains items the use of multimedia in teaching. This questionnaire is built using a Likert scale of 1 to 5. Likert scale was chosen is to reduce measurement error. In the questionnaire also, it contains five levels, representing strongly disagree, disagree, disagree, agree and strongly agree. Examples Likert scale used is shown in Table 2.

Table 2. Table-level Likert scale of 1 to 5 .

\begin{tabular}{lll}
\hline Num. & Level of Agreement & Scale \\
\hline 1. & Strongly Disagree & 1 \\
2. & Disagree & 2 \\
3. & Somewhat agree & 3 \\
4. & Agree & 4 \\
5. & Strongly agree & 5 \\
\hline
\end{tabular}

Validity and reliability of instruments for determining the validity of this legal instrument, an experienced specialist role is to evaluate the items contained in the questionnaire. Danis face validity of the questionnaire was obtained from a lecturer in Information Technology from the Community College of Bandar Penawar. A pilot study was conducted on 10 teachers in Community College of Bandar Penawar to determine the reliability of the questionnaire. However, this is not the respondent pilot study respondents will be involved to the real study. The result of pilot studies the reliability of the questionnaire items was 0.80 . Data were analyzed using the Statistical Package for Social Science (SPSS) version 12.0. Descriptive statistics were used as percentage, mean, standard deviation and frequency.

\section{Finding}

In the following sections, findings of this review are presented in three main sections according to the basic data analyses, research methods analyses, and content analyses. Findings from the analyses of discussion such as identified issues, gaps in research and insights that emerged are incorporated into the findings.

The respondents comprised of 40 teachers at three training institutions. From the aspect of gender findings indicate the number of respondents, most were men, 22 women, or 55 per cent compared to the 18 or 45 percent. Response is the busiest woman from Bandar Penawar Community College of 15 people or 37.5 per cent. From the aspect of teaching experience, data showed instructors with teaching experience ranging from 6 to 10 years $(\mathrm{n} 16,40)$ of instructors teaching experience under 5 years $(\mathrm{N} 15,37.5)$, while the instructors have experience teaching between 11 to 15 years is A total of 8 patients (20), 16 to 20 years: $1(0.4)$ and no more than 20 years of teaching. From the aspect of teaching by clusters, engineering another field that is exceed a total of 18 (45) trainers. Whereas the mechanical engineering staff of 16 (40) and electrical engineering of 6 (15). At least the teaching field of hospitality 2 (5). Data also showed that all teachers $(40,100)$ of the respondents had some training in ICT.

Table 3. Profile of The Research Respondent.

\begin{tabular}{|c|c|c|c|}
\hline Backgroud Information & Category & Num. Sampel N=40 & Percentage $(\%)$ \\
\hline \multirow{2}{*}{ Gender } & Male & 22 & 55 \\
\hline & Female & 18 & 45 \\
\hline \multirow{5}{*}{ Teaching Experience } & Under 5 year & 15 & 37.5 \\
\hline & $6-10$ year & 16 & 40 \\
\hline & $11-15$ year & 8 & 20 \\
\hline & $16-20$ year & 1 & 0.4 \\
\hline & Above 20 year & 0 & 0 \\
\hline \multirow{4}{*}{ Field Of Teaching Cluster } & Mechanical Engineering & 16 & 40 \\
\hline & Civil Engineering & 18 & 45 \\
\hline & Electrical Engineering & 6 & 15 \\
\hline & Hospitality & 2 & 5 \\
\hline \multirow{2}{*}{ Attending Course of ICT } & Yes & 40 & 100 \\
\hline & Never & 0 & 0 \\
\hline
\end{tabular}

\subsection{Multimedia Skills Levels Among the Instructors of Basic ICT Skills}

Skill level is measured based on five categories Multimedia applications. According to Table 4, the results showed highly skilled trainers $(\mathrm{M}=3.56, \mathrm{SD}=.49)$ in basic operation of such control computers using hardware, manage files, print documents and scan (scan) virus. Word processing applications available for trainers to be at high level (consummate) using Microsoft Word $(\mathrm{m}=3.59, \mathrm{SD}=.53)$. 
They can use the included software to edit the text, import graphics and tables. Trainers also available proficient $(\mathrm{M}=$ 2.92 , SD =.69) using spreadsheet applications such as enter and edit data, build tables, use the formula and analyze data. In addition, available skilled trainers using Microsoft Power Point $(\mathrm{M}=2.89, \mathrm{SD}=.82)$ where they can produce a slide and insert multimedia elements (audio, graphics, animation, text, video) and hyperlinks. For Internet applications, available skilled trainers $(\mathrm{M}=2.68, \mathrm{SD}=.54)$ using e-mail, web surfing, upload and download materials.

Table 4. Basic Skill Level of Multimedia.

\begin{tabular}{llll}
\hline Skills & Mean & $\begin{array}{c}\text { Standard } \\
\text { Deviation }\end{array}$ & \\
\hline Computer Operation Skills & 3.56 & .49 & High (Highly Skilled) \\
Word Processing & 3.59 & .53 & High (Highly Skilled) \\
Spreadsheet multimedia & 2.92 & .69 & Average (Advanced) \\
Presentation multimedia & 2.89 & .82 & Average (Advanced) \\
internet applications & 2.68 & .54 & Average (Advanced) \\
Overview & 3.13 & .54 & High (Highly Skilled) \\
\hline
\end{tabular}

Leader skills Table 5 below to identify methods of teaching using multimedia software among trainers training institutions. The findings show that the teaching methods used most frequently is tutorial that 34 of them (85). This method may often be used because tutorial is teaching and learning methods that are more of a guidance and training given to students. While the methods of drills that 30 people (75) using multimedia in teaching. This is because the exercises are used to increase the understanding and mastery of various skills through training.

Table 5. Method of teaching using multimedia software by instructors.

\begin{tabular}{lllll}
\hline \multirow{2}{*}{$\begin{array}{l}\text { Teaching } \\
\text { Method }\end{array}$} & \multicolumn{2}{l}{ Number Instructor Use } & \multicolumn{2}{c}{ Number Instructor Use } \\
\cline { 2 - 5 } & $\boldsymbol{f}$ & $\%$ & $\boldsymbol{F}$ & $\%$ \\
\hline Instructor Guide & 34 & 85 & 6 & 15 \\
Simulation & 26 & 65 & 14 & 35 \\
Demonstration & 20 & 50 & 20 & 50 \\
Drilling & 30 & 75 & 10 & 25 \\
\hline
\end{tabular}

\subsection{Frequency of Using Multimedia in Teaching}

Through this instrument the researchers have identified the level of the frequency of respondents to use multimedia in teaching. The study found that none of the respondents never use multimedia in teaching, 40 had used it only once, never use multimedia software 22.5 by 2 or 3 times a month, 25 multimedia software at least once a week, a total of 5 patients (12.5) stated that they had use more than once a week. Based on the table above, a total of 15 out of 40 respondents are active use of 37.5. (Often and very often). Meanwhile, more than half of 25 out of 40 respondents are passive users (rarely used), which is 62.5. However, none of the institutions involved in this study had never used multimedia software in the teaching process. The table of frequency of use of multimedia in teaching as shown as Table 6.

Table 6. Frequency of use of multimedia in teaching.

\begin{tabular}{llll}
\hline Item & Note & $\begin{array}{l}\text { Frequency } \\
(\mathbf{N = 4 0 )}\end{array}$ & $\begin{array}{l}\text { Percentage } \\
(\mathbf{1 0 0 \% )}\end{array}$ \\
\hline Never used & & 0 & 0 \\
Rarely used & Occasionally 2 or 3 times & 16 & 40 \\
Often & a month & 9 & 22.5 \\
Very often & At least once a week & 10 & 25 \\
& More than once a week & 5 & 12.5 \\
& Total & 40 & 100.0 \\
\hline
\end{tabular}

\section{Conclusion and Recommendation}

This brief study was carried out to get an idea of the level of skill and the use of multimedia in teaching burden in skills training centers. Through this study has successfully identified the skills and the use of multimedia in teaching burden. While the frequency of use in teaching is found to be at average and should be further enhanced.

However, faculty member positive view of the importance of the use of multimedia in teaching and education nowadays, although there are some obstacles and challenges for educators. Especially in training institutions should always take the initiative to improve the skills and the provision of teaching materials in the form of multimedia make teaching and learning more effective and interesting for students and understanding. ICT facilities also need to be further enhanced in skills training centers to facilitate the use and encourage trainers to use them. If successful implement will indirectly raise the level of education, skills training institutions in line with the development of technology nowadays.

Researchers want to give some suggestions to TVET trainers to enhance the use of multimedia in teaching and learning:

i. To provide courses related to computer use skills to improve the technical skills as the use of multimedia in teaching and others.

ii. the coach need initiative to attend courses outside the department.

iii.ensuring that the lecturers are always committed to high while using multimedia software, mentor mentee program can help others who are less skilled lecturers.

\section{References}

[1] Abd. Rahman Daud. (2000). Kefahaman terhadap konsep penggunaan ICT di dalam bilikdarjah. Proceedings of the International Conference on Teaching and Learning, 609-623

[2] Waterworth, J A (1992) Multimedia Interaction: Human Factors Aspects. Chichester, UK: Ellis Horwood, 1992

[3] Babbitt, B. C (2000) Tips For Software selection for Math Instruction. Atas Bachelor Pendidikan (Bimbingan dan Kaunseling). Fakulti Pengajian

[4] E. F. (pnyt.). Contemporary issues in curriculum. Edisi ke-3, 268-272. Boston: Pearson Education 
[5] Jamalludin Harun dan Zaidatun Tasir, (2003). "Pendapat Pelajar Terhadap Reka Bentuk Perisian Multimedia yang Berasaskan Kepada Pendekatan Pembelajaran Konstruktivis". Universiti Teknologi Malaysia (UTM) Skudai

[6] Mohammed Sani Hj Ibrahim, Jamalul Lail Abdul Wahab dan Mohd Izham Mohd Hamzah. (2001). Kajian Keberkesanan Program Latihan Guru Bestari dan Impaknya terhadap Pembelajaran Pelajar. Prosiding Konvensyen Teknologi Pendidikan Kali Ke-14. Universiti Kebangsaan Malaysia. Pp 363-394

[7] Koay, Chung Chuan (1995). "Satu Tinjauan Pengalaman Menggunakan Alat Bantu Mengajar (ABM) Di Kalangan Guru-Guru Ketukangan (Yang melanjutkan pengajian di UTM) semasa di Sek. Men. Vokasional." Universiti Teknologi Malaysia: Tesis Sarjana Muda

[8] Mohamad Najib Abdul Ghafar (1999). Penyelidikan Pendidikan. Johor: Universiti Teknologi Malaysia

[9] Tapscott, D. (2003). Educating the net generation. Dlm. Ornstein, A. C., Behar-Horenstein, L.\& Pajak

[10] Ibrahim, M. S, Abdul Wahab, J. L dan Mohd Hamzah, M. I., (2001). Kajian Keberkesanan Program Latihan Guru Bestari dan Impaknya terhadap Pembelajaran Pelajar. Prosiding Konvensyen Teknologi Pendidikan Kali Ke-14. Universiti Kebangsaan Malaysia. Pp 363-394
[11] Mohd Hasril Amiruddin, Faizal Amin Nur Yunus, Mohamad Hisyam Mohd Hashim, Mohd Bekri Rahim, Mohd Luqman Abd Rahim. Application of Communication Skills (CS) Among Lecturer on Vocational Teaching and Learning in Vocational College Zone Johor, Malaysia. International Journal of Vocational Education and Training Research. Vol. 1, No. 4, 2015, pp. 55-61. doi: 10.11648/j.ijvetr.20150104.11

[12] Mohamad Hisyam Mohd Hashim (2015). Using Technology and Instructional E-Material among technical teacher and student into teaching and learning: A qualitative case study. International Education Studies. Vol. 8, No. 3; 2015, pg 175-180. doi: 10.5539/ies.v8n3p175

[13] Jacquetta Megarry (1990). Assesment and Evaluation. Kogan Page and Named Distributors. London.

[14] Rosenberg, Scott (2007). Dreaming in Code. Two Dozen Programmers, Three Years, 4,732 Bugs, and One Quest for Transcendent Software. New York

[15] Ellis, R (2004). The definition and measurement of explicit knowledge. Language Learning, 54, 227-275

[16] Ismail, N. \& Wok, S. (2002). Kursus Komunikasi Organisasi. Kuala Lumpur Universiti Putra Malaysia 